\title{
Impacts of Climate Change on Water Resources in Diyala River Basin, Iraq
}

\author{
Nahlah Abbas ${ }^{1}$, Saleh A Wasimi ${ }^{1}$ and Nadhir Al-Ansari ${ }^{2}$ \\ 1. School of Engineering and Technology, Central Queensland University, Melbourne 3000, Australia \\ 2. Department of Civil, Environmental and Natural Resources Engineering, Lulea University of Technology, Lulea 971 87, Sweden
}

\begin{abstract}
Diyala River is the third largest tributary of the Tigris River running $445 \mathrm{~km}$ length and draining an area of $32,600 \mathrm{~km}^{2}$. The river is the major source of water supply for Diyala City for municipal, domestic, agriculture and other purposes. Diyala River Basin currently is suffering from water scarcity and contamination problems. Up-to-date studies have shown that blue and green waters of a basin have been demonstrating increasing variability contributing to more severe droughts and floods seemingly due to climate change. To obtain better understanding of the impacts of climate change on water resources in Diyala River Basin in near 2046 2064 and distant future 2080 2100, SWAT (soil and water assessment tool) was used. The model is first examined for its capability of capturing the basin characteristics, and then, projections from six GCMs (general circulation models) are incorporated to assess the impacts of climate change on water resources under three emission scenarios: A2, A1B and B1. The results showed deteriorating water resources regime into the future.
\end{abstract}

Key words: Diyala River, SWAT model, blue water, green water, Iraq.

\section{Introduction}

Recently, the impacts of climate change on water resources have become a major concern that world has to cope with. Hydrological cycles can be significantly impacted by climate change mainly through the modification of precipitation and evapotranspiration [1-3]. These changes often manifest as severe drought and devastating floods imparting greater variability in river discharge and soil moisture [4].

Iraq is considered as arid or semi-arid with less than $150 \mathrm{~mm}$ of rain annually and high evaporation rate [5]. The country is highly vulnerable to climate change and variability because of its aridity [5]. Climate change is one of the greatest challenges confronting Iraq [6-10], it could have significantly adverse effects on water resources and hence the environment and economy, particularly on the agricultural sector. In recent time, Iraq has experienced several devastating climate extremes. For example, two years severe

Corresponding author: Nadhir Al-Ansari, professor, research fields: water resources and environmental engineering. drought that occurred between 2007 and 2009 followed by some months of an extreme rainfall during which large parts of central and southern of Iraq experienced increasing in rainfall by $200 \%$ of normal amount [11]. Diyala River Basin is the third greatest tributary of the Tigris River running $445 \mathrm{~km}$ length and draining an area of $32,600 \mathrm{~km}^{2}$. The river is the main source of water supply for Diyala City for municipal, domestic, agriculture and other purposes. Diyala River Basin currently is suffering from water scarcity and contamination problems. Up to date, water issues related to climate change in the Diyala catchment have not been well addressed within climate change analyses and climate policy construction [12]. Therefore, the main objective of this study has been to evaluate the potential future climatic changes on the water sources of Diyala, specifically blue and green waters. The computer-based hydrological model SWAT (soil and water assessment tool) has been used to explore the effects of climatic change on stream flow of the study area. The model was set at monthly scale using 
available spatial and temporal data and calibrated against measured stream flow. Climate change scenarios were obtained from general circulation models.

\section{Studied Area}

Diyala River (Fig. 1) originates in the Zagros Mountains in Iran, shaping the Iran-Iraq border for more than $30 \mathrm{~km}$ [13]. The basin is situated between $33.216^{\circ} \mathrm{N}$ and $35.833^{\circ} \mathrm{N}$, and $44.500^{\circ} \mathrm{E}$ and $46.833^{\circ}$ E. Its main tributaries are the Sirwan, Tanjeru and Wand Rivers [14]. The Diyala River links Tigris River $15 \mathrm{~km}^{2}$ south of Baghdad. More dams have been built along the Diyala River compared to other Tigris tributaries. Three dams have been built within Iraqi part (Derbendikhan Dam, Hemrin Dam, Diyala Weir) for multi uses. In spite the construction of these dams, no significant influence on flow volumes and flow regime has been detected [11]. Mean annual precipitation is $420 \mathrm{~mm}$ and mean annual temperature is $36{ }^{\circ} \mathrm{C}$. The Diyala flow regime is a highly seasonal flow with peak flow occurring in April and low seasonal flow from July to December. Approximately $77 \%$ of the watershed is covered by forest; $23 \%$ of the land is used for agricultural activities.

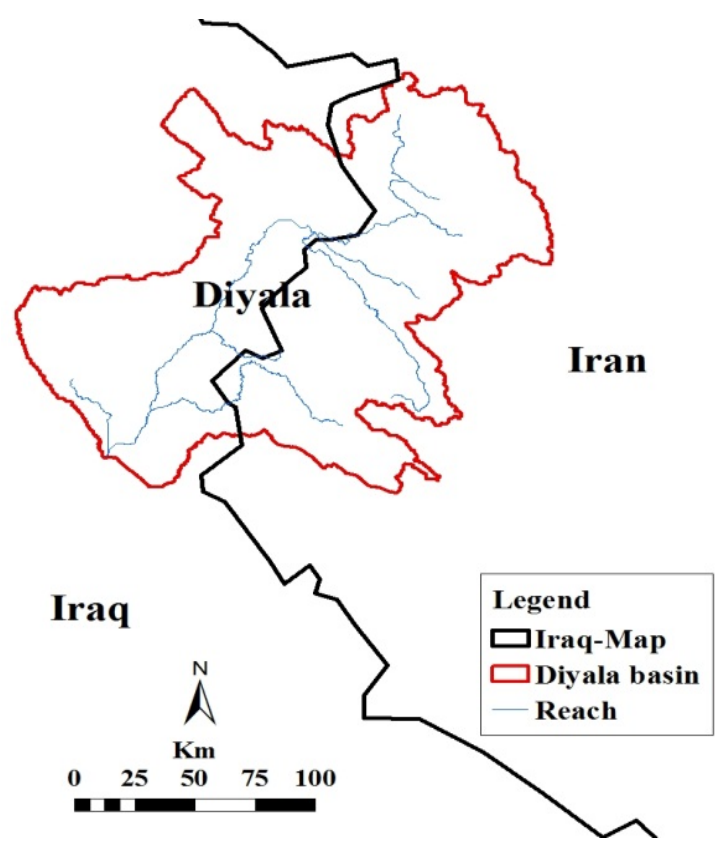

Fig. 1 Location of Diyala River Basin.

\section{Description of SWAT Model}

SWAT [15] is a river watershed scale, semi-distributed, and physically based continuous time (daily computational time step) mathematical model for analysing hydrology and water quality at various watershed scales with varying soils, land use and management conditions on a long-term basis. The SWAT model originally was developed by the USDA (United States Department of Agriculture) and the ARS (agricultural Research Service) at the Grassland, Soil and Water Research Laboratory in Temple, Texas, USA [16]. SWAT system is embedded within a Geographic Information System (ArcGIS interface), in which different spatial environmental data, including climate, soil, land cover and topographic characteristics can be integrated.

Two major divisions, land phase and routing phase, are conducted to simulate the hydrology of a watershed. The land phase of the hydrological cycle predicts the hydrological components including surface runoff, evapotranspiration, groundwater, lateral flow, ponds, tributary channels and return flow. The routing phase of the hydrological cycle includes the movement of water, sediments, nutrients and organic chemicals via the channel network of the basin to the outlet [15]. In the land phase of the hydrological cycle, the simulation of the hydrological cycle is based on the water balance equation:

$$
S W_{t}=S W_{0}+\sum_{i=1}^{n}\left(R_{\text {day }}-Q_{\text {surf }}-E_{a}-W_{\text {seep }}-Q_{g w}\right)
$$

where, $S W_{t}$ is the final soil water content (mm), $S W_{0}$ is the initial soil water content on day $i(\mathrm{~mm}), R_{d a y}$ is the amount of precipitation on day $i(\mathrm{~mm}), Q_{\text {surf }}$ is the amount of surface runoff on day $i(\mathrm{~mm}), E_{a}$ is the amount of evapotranspiration on day $i(\mathrm{~mm}), W_{\text {seep }}$ is the amount of water entering the vadose zone from the soil profile on day $i(\mathrm{~mm})$, and $Q_{g w}$ is the amount of return flow on day $i(\mathrm{~mm})$.

The SWAT model allows users to estimate surface runoff through two methods: the SCS (Soil Conservation Service) curve number procedure (SCS 
1972 in Ref. [15] and the Green and Ampt infiltration method [17]). The SCS method was used in this study due to non-availability of sub-daily data that is essential by the Green and Ampt infiltration method. The model calculates the volume of lateral flow based on the variation in conductivity, slope and soil water content. A kinematic storage model is utilized to predict lateral flow through each soil layer. Lateral flow occurs below the surface when the water rates in a layer exceed the field capacity after percolation. The groundwater simulation is divided into two aquifers which are a shallow aquifer (an unconfined) and a deep confined aquifer in each watershed. The shallow aquifer contributes to stream flow in the main channel of the watershed. Water that percolates into the confined aquifer is presumably contributing to stream flow outside the watershed. Three methods are provided by SWAT model to estimate PET (potential evapotranspiration): the Penman-Monteith method [18], the Priestley-Taylor method [19] and the Hargreaves method [20]. The Penman-Monteith method requires air temperature, wind-speed, solar radiation and relative humidity; Priestley-Taylor method needs air temperature and solar radiation, while Hargreaves method needs only daily temperature as inputs. Water is routed through the channel network by applying either the variable storage routing or Muskingum River routing methods using the daily time step.

\subsection{Model Input}

The data required by SWAT for modelling includes DEM (digital elevation model), land use map and soil map, weather data and discharge data. DEM was extracted from ASTERGDM (ASTER Global Digital Elevation Model) with a $30 \mathrm{~m}$ grid and $1 \times 1$ degree tiles. ${ }^{1}$ The land cover map was obtained from the European Environment Agency $^{2}$ with a $250 \mathrm{~m}$ grid raster for the year 2000. The soil map was collected

\footnotetext{
${ }^{1}$ http://gdem.ersdac.jspacesystems.or.jp/tile_list.jsp.

${ }^{2} \mathrm{http} / / / \mathrm{www}$.eea.europa.eu/data-and-maps/data/global-land-cov er- $250 \mathrm{~m}$.
}

from the global soil map of the Food and Agriculture Organization of the United Nations [21]. Weather data which includes daily precipitation, 0.5 hourly precipitations, maximum and minimum temperatures were obtained from the Iraq's Bureau of Meteorology. Monthly stream flow was collected from the Iraqi Ministry of Water Resources/National Water Centre.

\subsection{Model Setup}

In SWAT, the watershed is divided into sub-basins based on the DEM. The land use map, soil map and slope datasets are embedded with the SWAT databases. Thereafter, sub-basins are further delineated by HRUs (Hydrologic Response Units). HRUs are defined as packages of land that have a unique slope, soil and land use area within the borders of the sub-basin. HRUs permit the user to identify the differences in hydrologic conditions such as evapotranspiration for varied soils and land uses. Routing of water and pollutants are predicted from the HRUs to the sub-basin level and then through the river system to the watershed outlet.

\subsection{Model Calibration and Validation (SUFI-2 Algorithm Description)}

The sequential uncertainty fitting algorithm application (SUFI-2) embedded in the SWAT-CUP package [22] was used to evaluate the performance of SWAT. The advantages of SUFI-2 are that it combines optimization and uncertainty analysis, can handle a large number of parameters through Latin hypercube sampling, and it is easy to apply [23]. Furthermore, as compared with other different techniques used in SWAT such as GLU (generalized likelihood uncertainty) estimation, parameter solution (parsol), MCMC (Markov chain Monte Carlo), SUFI-2 algorithm was found to obtain good prediction uncertainty ranges with a few number of runs [23, 24]. This efficiency is of great significance when implementing complex and large-scale models [23, 25].

The SUFI-2 first identifies the range for each 
parameter. After that, Latin hypercube method is used to generate multiple combinations among the calibration parameters. Finally, the model runs with each combination and the obtained results are compared with observed data until the optimum objective function is achieved. Since the uncertainty in forcing inputs (e.g., temperature, rainfall), conceptual model and measured data are not avoidable in hydrological models, the SUFI-2 algorithm computes the uncertainty of the measurements, the conceptual model and the parameters by two measures: $P$-factor and $R$-factor. $P$-factor is the percentage of data covered by the $95 \%$ PPU (prediction uncertainty) which is quantified at $2.5 \%$ and $97.5 \%$ of the cumulative distribution of an output variable obtained through Latin hypercube sampling [22]. The $R$-factor is the average width of the 95 PPU divided by the standard deviation of the corresponding measured variable. In an ideal situation, $P$-factor tends towards 1 and $R$-factor to 0 [22]. The objective of the algorithm is to increase $P$-factor and reduce $R$-factor in order to achieve the optimal parameter range. These factors together reflect the strength of the calibration-uncertainty analysis. Further, SUFI-2 calculates the coefficient of determination $\left(R^{2}\right)$ and the ENC (Nasch-Sutcliff efficiency) [26] to assess the goodness of fit between the measured and simulated data. $R^{2}$ shows the strength of the relationship between the simulated and observed data. It ranges from 0 to 1 [27]. The higher values of $R^{2}$ reflect less error variance, and values greater than 0.5 are satisfactory [28]. $R^{2}$ has been widely used to provide an assessment of climate change detection, hydrological and hydroclimatological applications $[27,29] . R^{2}$ is given by:

$$
R^{2}=\left[\frac{\sum_{i=1}^{n}\left(O_{i}-\bar{O}\right)\left(P_{i}-\bar{P}\right)}{\left[\sum_{i=1}^{n}\left(O_{i}-\bar{O}\right)^{2}\right]^{0.5}\left[\left(\sum_{i=1}^{n} P_{i}-\bar{P}\right)^{2}\right]^{0.5}}\right]^{2}
$$

where, $O_{i}$ is the observed stream flow, $P_{i}$ is the simulated stream flow, $\bar{O}$ is the mean observed stream flow during the evaluation period and is the mean simulated stream flow for the same period.

The ENC value is an indication of how well the plot of the observed against the simulated values fits the 1:1 line. It can range from negative infinity $(-\infty)$ to 1 . The closer the value to 1 , the better the prediction is, while the value of less than 0.5 indicates unsatisfactory model performance [28]. ENC is calculated as shown below:

$$
E N C=1-\left[\frac{\sum_{i=1}^{n}\left(O_{i}-P_{i}\right)^{2}}{\sum_{i=1}^{n}\left(O_{i}-\bar{O}\right)^{2}}\right]
$$

$E N C$ was recommended to be used for calibration for two reasons: first, it has been adopted by ASCE (American Society of Civil Engineers) [30] and second, Legates and McCabe [27] recommend it due to its straightforward physical interpretation [31]. Besides, it has been found wide applications offering extensive information on reported values [28].

SUFI-2 permits users to conduct global sensitivity analysis, which is computed based on the Latin hypercube and multiple regression analysis. The multiple regression equation is defined as below:

$$
g=\alpha+\sum_{i=1}^{m} \beta_{i} * b_{i}
$$

where, $g$ is the value of evaluation index for the model simulations, $\alpha$ is a constant in multiple linear regression equation, $\beta$ is the coefficient of the regression equation, $b$ is a parameter generated by the Latin hypercube method and $m$ is the number of parameters.

The $t$-stat of this equation which indicates parameter sensitivity is applied to determine the relative significance for each parameter, the more the sensitive parameter, the greater is the absolute value of the $t$-stat [22]. $P$-value is an indication of the significance of the sensitivity, $P$-value close to 0 has more significance.

\subsection{GCM (General Circulation Model) Inputs}

Six GCMs from CMIP3 namely CGCM3.1/T47, CNRM-CM3, GFDL-CM2.1, IPSLCM4, MIROC3.2 
(medres) and MRI CGCM2.3.2 were nominated for climate change projections in the Diyala basin under three commonly used scenarios, an extreme high emission scenario (A2), a moderate emission scenario (A1B) and a low emission scenario (B1) for two future periods (2046 2064 and 2080 2100). The projected temperatures and precipitation were then applied to the SWAT model to compare water resources in the basin with the baseline period (1980 2010). BCSD method was used to downscale the GCM results [32].

\section{Results and Discussion}

\subsection{Sensitivity Analysis}

Sensitivity analysis was conducted for 25 parameters related to stream flow (Table 1), from which 12 most sensitive parameters were considered for implementing the model calibration for the Diyala basin.

The ranking of 12 uppermost sensitive parameters for the basin is shown in Table 2. CN2 was the most sensitive parameter. In most SWAT applications in different basins, $C N 2$ was observed to be the highest sensitive parameter $[33,34]$. $A L P H A \_B F$ was observed to be the second highest sensitive parameter and the most sensitive parameter among ground water parameters. $G W \_D E L A Y$ was ranked the third.

\subsection{Calibration and Validation}

SWAT was calibrated and validated for Diyala basin on a monthly scale at Derbendi-Khan station located between Latitude $35.08^{\circ} \mathrm{N}$ and Longitude $45.45^{\circ}$ E. The model was calibrated for 18 years (1979-1996) and validated for 8 years (1997-2004).

Table 1 Description of input parameters of stream flow selected for model calibration.

\begin{tabular}{|c|c|c|c|}
\hline Group & Parameter & Description & Unit \\
\hline \multirow{4}{*}{ Soil } & $S O L \_A L B$ & Moist soil albedo & - \\
\hline & $S O L \_A W C$ & Available water capacity & $\mathrm{mm} \cdot \mathrm{mm}^{-1}$ \\
\hline & SOL_K & Saturated hydraulic conductivity & $\mathrm{mm} \cdot \mathrm{h}^{-1}$ \\
\hline & $S O L \_Z$ & Depth to bottom of second soil layer & $\mathrm{mm}$ \\
\hline \multirow{5}{*}{ Groundwater } & $A L P H A \_B F$ & Base flow Alpha factor & days \\
\hline & GW_DELAY & Groundwater delay & days \\
\hline & $G W \_R E V A P$ & Groundwater "revap" coefficient & - \\
\hline & $G W Q M N$ & Threshold depth of water in the shallow aquifer for return flow to occur & $\mathrm{mm} \cdot \mathrm{H}_{2} \mathrm{O}$ \\
\hline & $R E V A P M N$ & Threshold depth of water in the shallow aquifer for 'revap' to occur & $\mathrm{mm} \cdot \mathrm{H}_{2} \mathrm{O}$ \\
\hline Subbasin & TLAPS & Temperature laps rate & ${ }^{\circ} \mathrm{C} \cdot \mathrm{km}^{-1}$ \\
\hline \multirow{4}{*}{ HRU } & $E P C O$ & Soil evaporation compensation factor & - \\
\hline & ESCO & Plant uptake compensation factor & - \\
\hline & $C A N M X$ & Maximum canopy storage & $\mathrm{mm} \cdot \mathrm{H}_{2} \mathrm{O}$ \\
\hline & SLSUBBSN & Average slope length & $\mathrm{m}$ \\
\hline \multirow{2}{*}{ Routing } & $\mathrm{CH} \_\mathrm{N2}$ & Manning's $\mathrm{n}$ value for the main channel & - \\
\hline & $\mathrm{CH} \mathrm{K}_{2}$ & Effective hydraulic conductivity in main channel alluvium & $\mathrm{mm} \cdot \mathrm{h}^{-1}$ \\
\hline \multirow{2}{*}{ Management } & BIOMIX & Biological mixing efficiency & - \\
\hline & $C N 2$ & Initial SCS runoff curve number for moisture condition II & - \\
\hline \multirow{7}{*}{ General data basin } & SFTMP & Snowfall temperature & ${ }^{\circ} \mathrm{C}$ \\
\hline & $S M F M N$ & Minimum melt rate for snow during year & $\mathrm{mm} \cdot \mathrm{H}_{2} \mathrm{O} \cdot{ }^{\circ} \mathrm{C}^{-1} \cdot$ day $^{-1}$ \\
\hline & $S M F M X$ & Maximum melt rate for snow during year & $\mathrm{mm} \cdot \mathrm{H}_{2} \mathrm{O} \cdot{ }^{\circ} \mathrm{C}^{-1} \cdot$ day $^{-1}$ \\
\hline & TEMP & Snow pack temperature lag factor & - \\
\hline & SURLAG & Surface runoff lag time & Days \\
\hline & $B L A I$ & Maximum potential leaf area index for land cover/plant & - \\
\hline & SLOPE & Slope & - \\
\hline
\end{tabular}


Table 2 Ranking of 12 highest sensitive parameters related to stream flow in the Diyala basin.

\begin{tabular}{llll}
\hline Parameter & Ranking & Initial values & Fitted values \\
\hline$C N 2$ & 3 & $-0.2 \sim 0.2$ & -0.09 \\
ALPHA_BF & 2 & $0 \sim 1$ & 0.27 \\
GW_DELAY & 4 & $50 \sim 450$ & 61.5 \\
SOL_AWC & 5 & $-0.2 \sim 0.4$ & 0.205 \\
SFTMP & 1 & $-5 \sim 5$ & -3.25 \\
HRU_SLP & 6 & $0 \sim 0.2$ & 0.015 \\
SLSUBBSN & 7 & $0 \sim 0.2$ & 0.005 \\
ESCO.hru & 8 & $0 \sim 0.2$ & 0.995 \\
SURLAG & 9 & $0.05 \sim 24$ & 13.4 \\
GWQMN & 10 & $0 \sim 2$ & 0.05 \\
CH_K2 & 11 & $5 \sim 130$ & 51.87 \\
GW_REVAP & 12 & $0 \sim 0.2$ & 0.155 \\
\hline
\end{tabular}

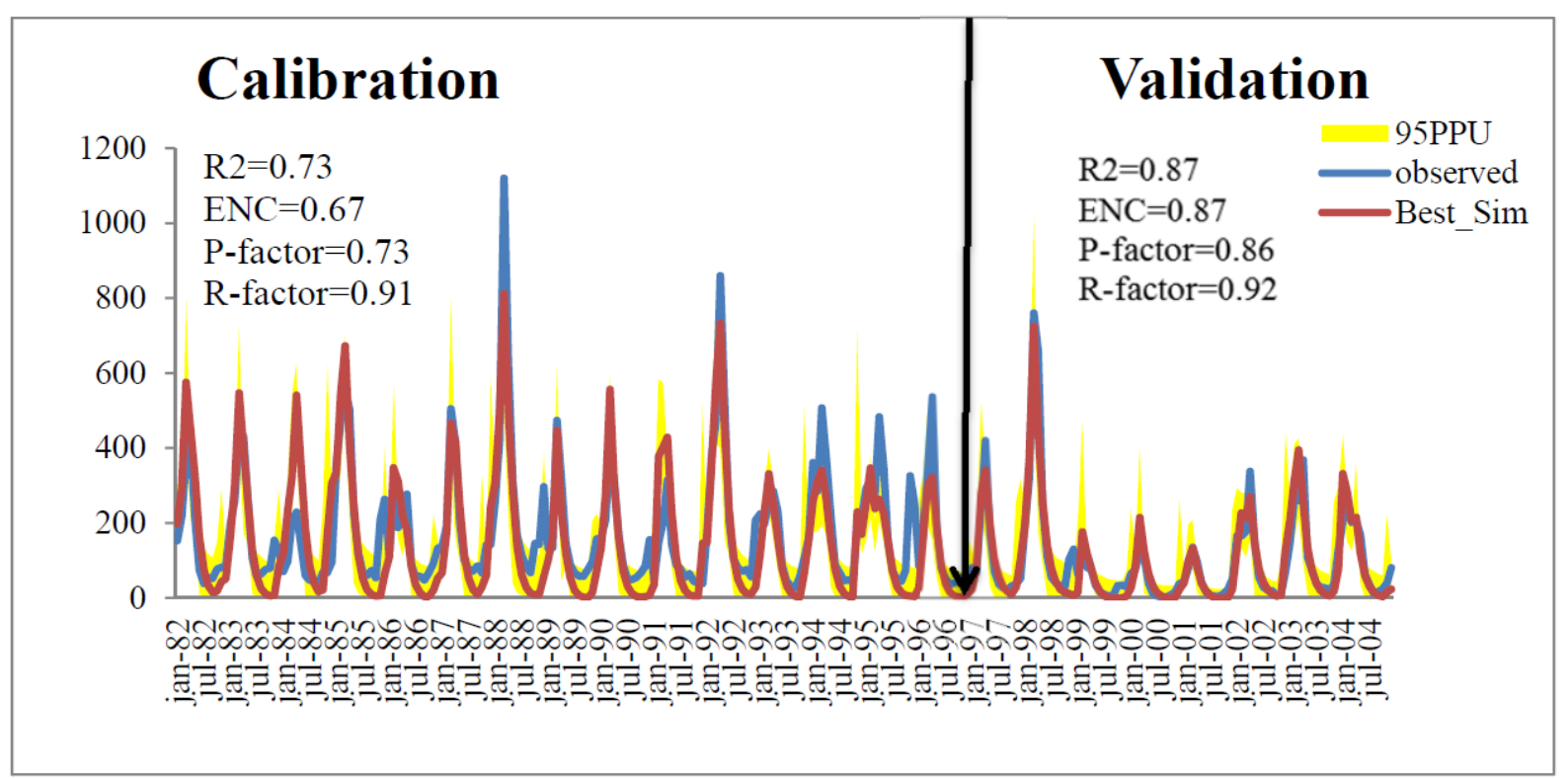

Fig. 2 Calibration and validation of the SWAT model at monthly scale at Derbendi-Khan within Diyala basin.

The first three years was set as a warm up. $R^{2}$ and $E N C$, estimated between the observed data and the best simulation in calibration and validation processes, indicated quite good results as shown in Fig. 2. In the calibration, $R^{2}, E N C$ and $P$-factor were $0.73,0.67$ and 0.73 , respectively. Both of $R^{2}$ and $E N C$ increased to 0.87 in the validation period and $P$ - factor increased to 0.86 .

\subsection{Trends in Precipitation, Blue Water and Green} Water Flows in the Last Three Decades

Using the calibrated model, annual precipitation, blue water (summation of water yield and deep aquifer recharge) and green water storage (soil water content) and green water flow (evapotranspiration) were estimated during the last three decades to detect the effects of climate change on the water cycle components.

The spatial and temporal distribution of precipitation over last three consecutive decades in the Diyala basin is shown in Fig. 3. Precipitation declined from upstream to downstream and from east to west of the basin. This is because the upper and east parts of the basin are mountainous with high precipitation and snowfall, whereas the lower and west part of the basin are relatively flat and experiencing less precipitation and no snowfall. From Fig. 3, it is evident that there is a general decreasing trend in precipitation 


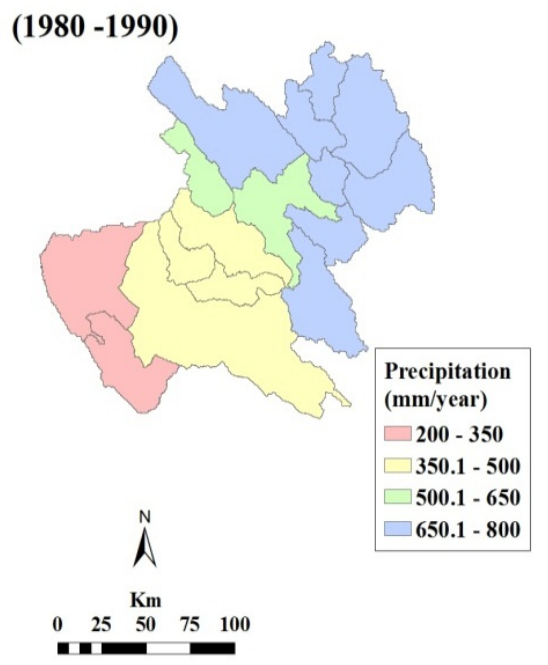

(a)

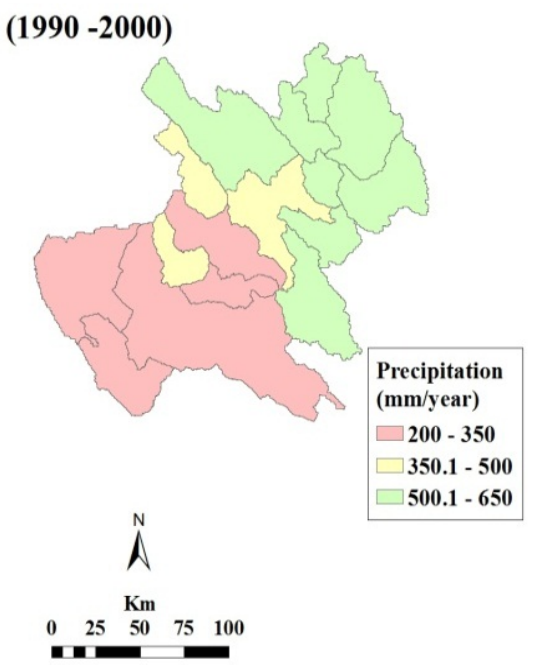

(b)

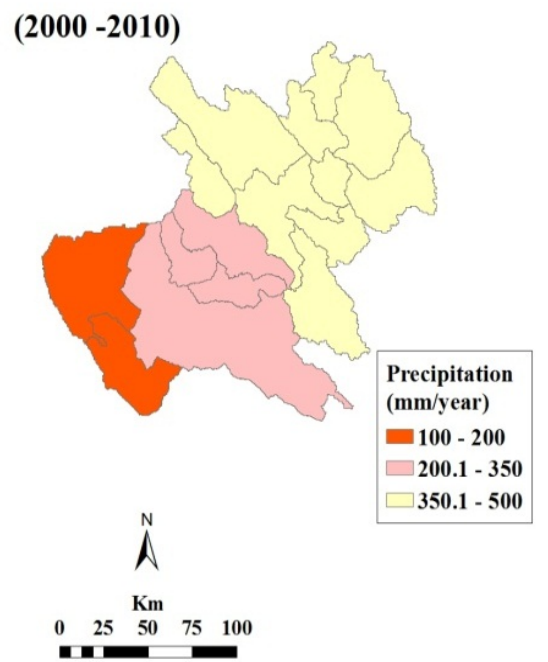

(c)

Fig. 3 Spatial distribution of precipitation in the Diyala basin over three consecutive decades: (a) 1980 1990; (b) 1990 2000; (c) $2000 \sim 2010$.

Table 3 Relative changes in precipitation, blue water and green water in the Diyala basin over three decades.

\begin{tabular}{llll}
\hline & & Rate of relative change in the last four decades \\
\hline Water component & 1990 s vs. 1980s & 2000 s vs. 1990s & 2000s vs. 1980s \\
\hline Blue water & -0.29 & -0.33 & -0.52 \\
Green water storage & -0.18 & -0.14 & -0.30 \\
Green water flow & -0.03 & -0.06 & -0.09 \\
\hline
\end{tabular}

over time. The 1990s and 2000s decades experienced decreases by about $18 \%$ and $35 \%$ compared to 1980 s decade, respectively (Table 3 ).

Blue water and green water storage in Diyala basin decreased from upstream to downstream following precipitation trends (Figs. 4 and 5), where precipitation is high blue water and green water storage tends to be high. Land cover also contributes to shaping blue water and green water storage trends.

In response to climate change and variability over last three decades, blue water decrease by $29 \%$ in 1990s decade and $33 \%$ in 2000 s decade in relative to 1980 s. Green water storage decreased by $18 \%$ and $30 \%$ in 1990 s and 2000 s decades, respectively. It is possible that the decreasing trends in the average annual blue water and green water are due to climate change. Green water flow was relatively constant during the three decades (Table 3) due to the assumption that land cover/and land use stayed unchanged during the period of 1980 to 2010.

\subsection{Blue Water Scarcity Indicators}

The four water stress levels shown in Fig. 6 tracks the commonly used water stress indicators introduced by Falkenmark [35] and Rijsberman [36]. Taking $1,700 \mathrm{~m}^{3}$ per capita is the water scarcity threshold [34]. The $1,700 \mathrm{~m}^{3} \cdot$ capita $^{-1} \cdot$ year $^{-1}$ is calculated based on estimations of water needs in the household, agricultural, industrial and energy sectors, and the demand of the environment [36]. A value equal or greater than $1,700 \mathrm{~m}^{3} \cdot$ capita $^{-1} \cdot$ year $^{-1}$ is classified as a sufficient to meet water demands. When water supply falls below $1,000 \mathrm{~m}^{3} \cdot$ capita $^{-1} \cdot$ year $^{-1}$, it is considered as water scarcity, and when below $500 \mathrm{~m}^{3} \cdot$ capita $^{-1} \cdot \mathrm{year}^{-1}$, it is extreme scarcity. The water availability per capita and water stress indicators were estimated for each of the sub basins of the Diyala basin using the 2.5 arcmin population map available from the CIESIN (Center for International Earth Science) GPW (Gridded Population of the World, version 3$)^{3}$ for 2005. Fig. 6

\footnotetext{
${ }^{3} \mathrm{http}: / /$ sedac.ciesin.columbia.edu/gpw.
} 


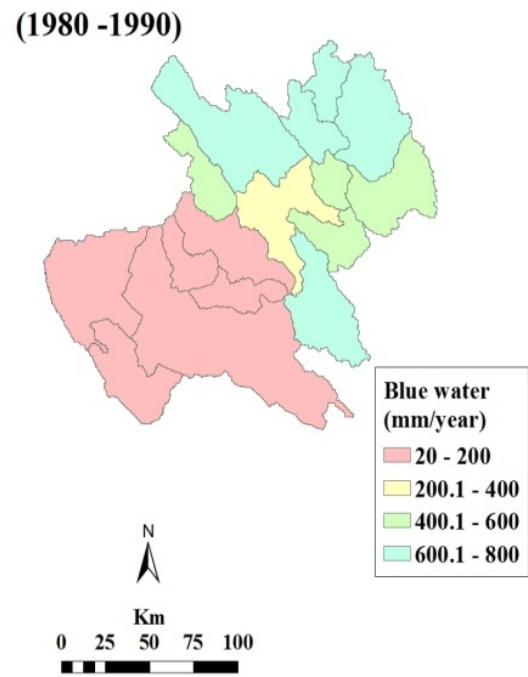

(a)

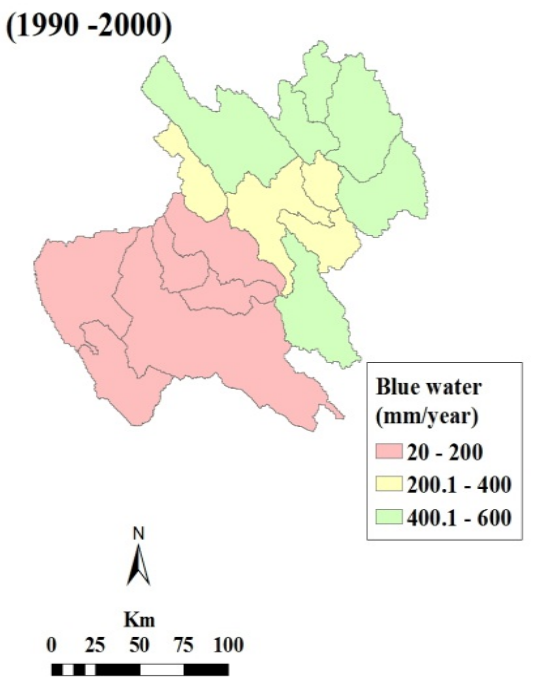

(b)

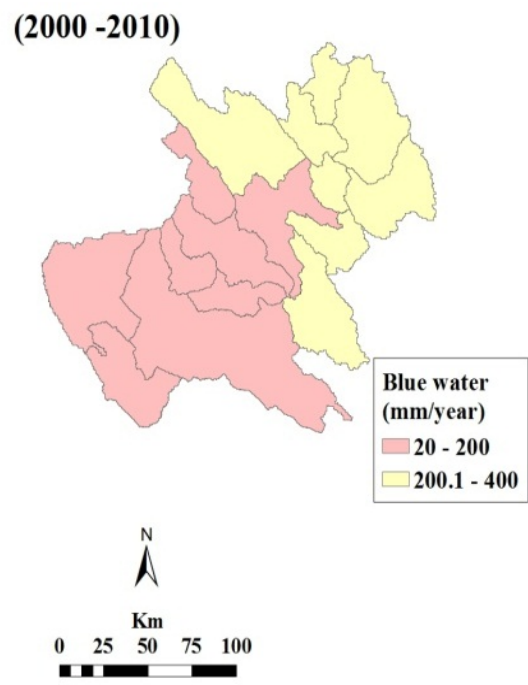

(c)

Fig. 4 Spatial distribution of blue water in the Diyala basin over three consecutive decades: (a) 1980 1990; (b) 1990 2000; (c) $2000 \sim 2010$.

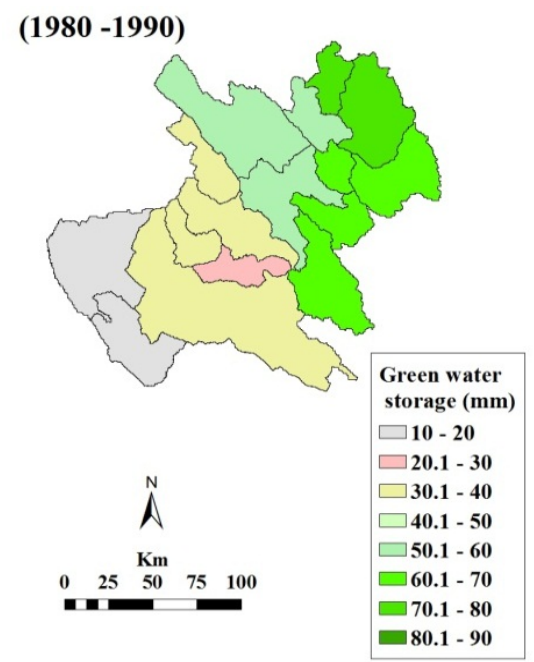

(a)

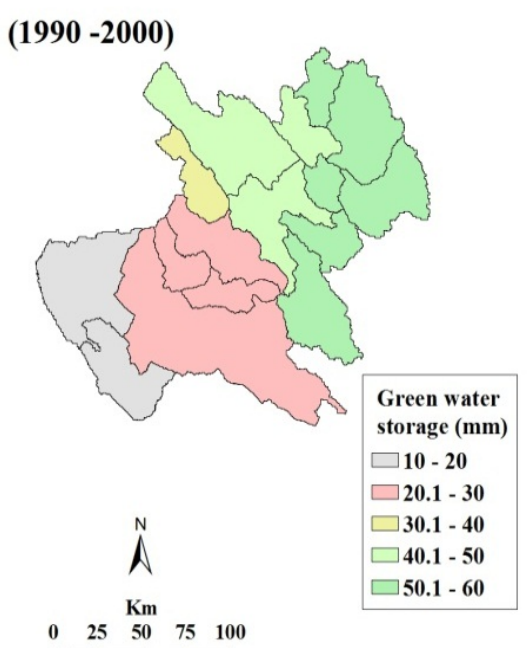

(b)

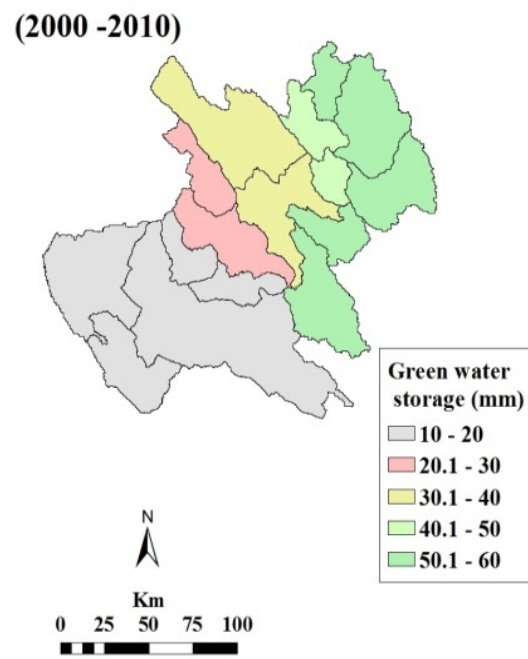

(c)

Fig. 5 Spatial distribution of green water storage water in the Diyala basin over three consecutive decades: (a) 1980 1990; (b) 1990 2000; (c) 2000 2010.

captures the spatial distribution of water resources per capita per year during the period of 1980 2010 based on the population estimates of the year of 2005 . Up to $56 \%$ of the basin area, mostly located in the downstream of the basin, suffered from extreme water scarcity. Thirty eight percent of the basin experienced blue water availability below 1,700 $\mathrm{m}^{3} /$ capita.year. Six percent only experienced adequate water blue which is located in the middle part of the basin.

\subsection{Uncertainty and Natural Variation in Green Water} Storage

For the rain fed crop yields, the average of the months per year for the period of 1980 to 2010 where green water storage is available (defined as $>1$ $\mathrm{mm} \cdot \mathrm{m}^{-1}$ ) is of greatest importance for water resources management [37]. Fig. 7a captures the special distribution of availability of green water storage referred as month/year. The downstream of the basin 


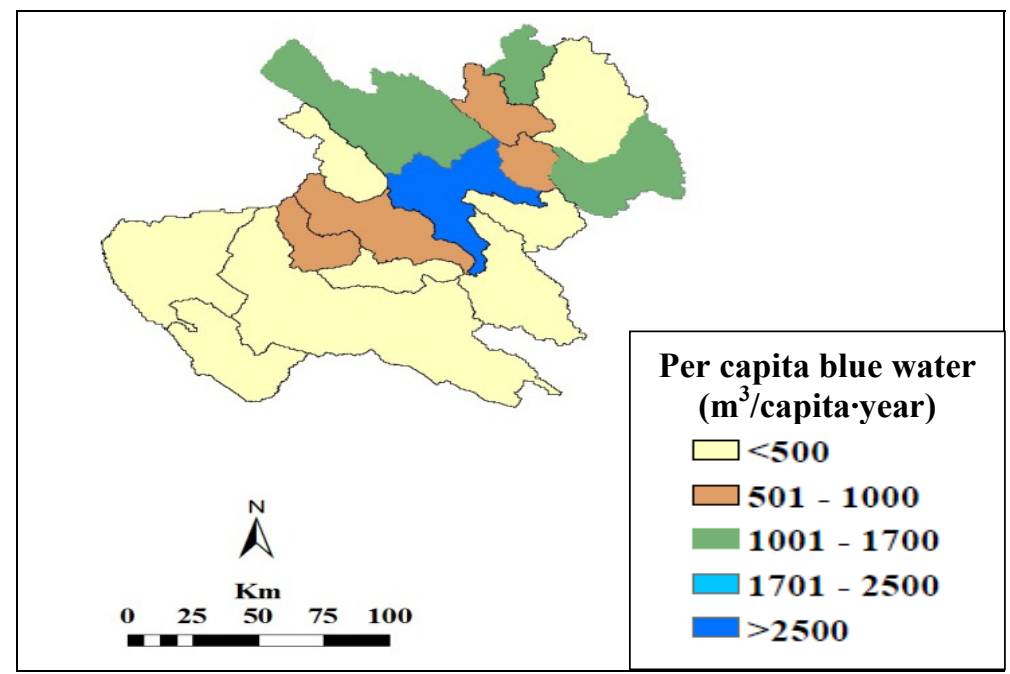

Fig. 6 Water scarcity in each modeled Diyala sub-basin represented by the modeled 1980 to 2010 annual average blue water flow availability per capita per year (using population of 2005) the average (Avg.) value of the 95PPU range.
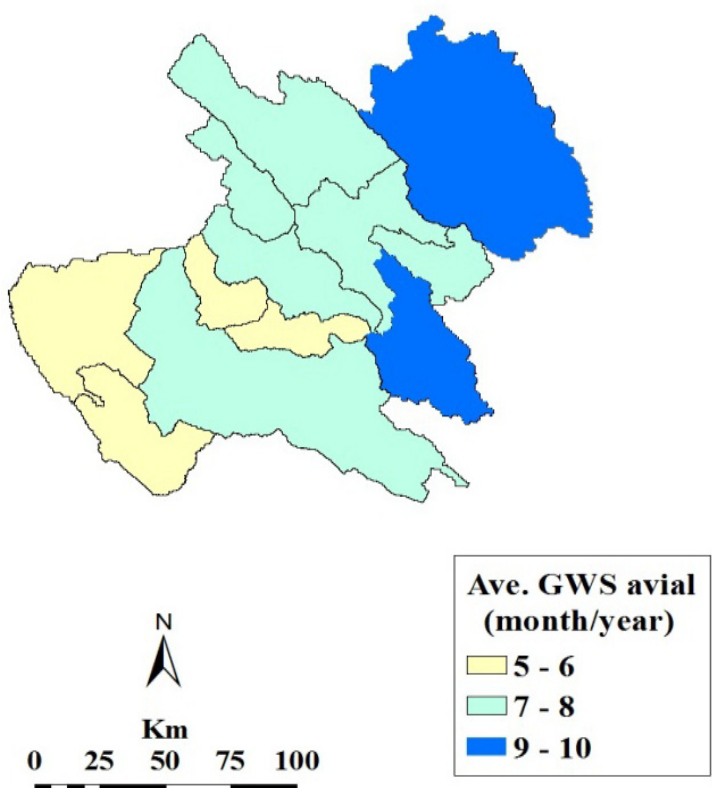

(a)
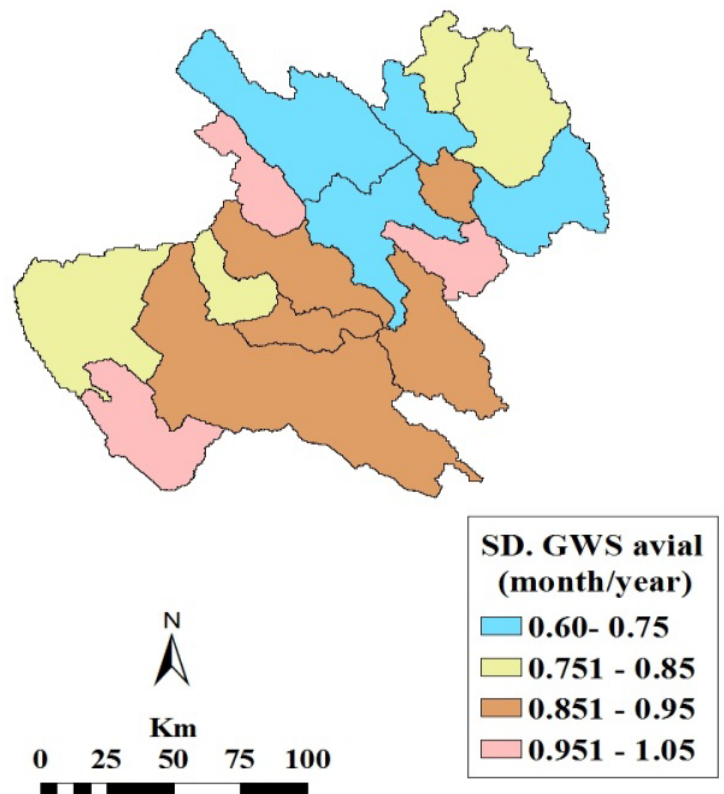

(b)

Fig. 7 The number of months per year where the green water storage (GW-S) is available for usage: (a) the 1980 2010 average; (b) SD.

(up to $20 \%$ of the basin) experienced 5 to 6 months (November to May) followed by the middle of the basin (7 8 months) and then the upstream of the basin (9-10 months) in which green water availability was available .The SD (standard deviation) of the months per year without depleted soil water is presented for the 1980 2010 period in Fig. 7b. The areas with a high $S D$ such as the lower part of the basin show high variability in green water storage availability. This might led to reduced crop yield. Adjusting irrigation systems and alternative cropping practices are highly suggested for sustainability of agriculture production in this part.

\subsection{The Impacts of Climate Change on Temperature and Precipitation}

Mean annual temperature and precipitation outputs from the six GCMs identified earlier were processed 
Table 4 GCM predicted changes in the mean annual temperature of the future under A2, A1B and B1 scenarios in Diyala basin.

\begin{tabular}{|c|c|c|c|c|c|c|}
\hline \multirow[t]{2}{*}{ Periods } & \multicolumn{6}{|c|}{ Annual change in mean temperature $\left({ }^{\circ} \mathrm{C}\right)$} \\
\hline & CGCM3.1/T47 & CNRM-CM3 & GFDL-CM2.1 & PSLCM4 & MIROC3.2 & MRI CGCM2.3.2 \\
\hline \multicolumn{7}{|l|}{$\mathrm{A} 2$} \\
\hline $2046 \sim 2064$ & 2.53 & 2 & 2.2 & 2.7 & 2 & 14 \\
\hline $2080 \sim 2100$ & 5.7 & 5.5 & 5.3 & 5.56 & 5.2 & 3.9 \\
\hline \multicolumn{7}{|l|}{ A1B } \\
\hline $2046 \sim 2064$ & 2.16 & 2.6 & 3 & 3.2 & 2.7 & 1.8 \\
\hline 2080 2100 & 4.29 & 4.6 & 5 & 5 & 5 & 3.4 \\
\hline \multicolumn{7}{|l|}{ B1 } \\
\hline $2046 \sim 2064$ & 1.7 & 1.7 & 1 & 1.4 & 1.5 & 1.4 \\
\hline 2080 2100 & 1.9 & 1.7 & 1.2 & 1.7 & 1.7 & 1.2 \\
\hline
\end{tabular}

for the Diyala basin under three scenarios (A2, A1B, and B1). Table 4 captures the projected changes in mean annual temperature for two future periods, 2046 2064 and 2080 2100, relative to base line period (1980 2010). Changes in mean temperature are highly likely to be steadier than precipitation. All the models showed constant increasing trends in temperature. Alterations in mean temperature modify evapotranspiration and precipitation and thus blue water and green water flows.

Fig. 8 captures the anomaly maps of precipitation distribution for $\mathrm{A} 2, \mathrm{~A} 1 \mathrm{~B}$ and $\mathrm{B} 1$ scenarios for the periods 2046 2064 and 2080 2100 in relative to 1980 2010 period for the average change of multi-GCM ensemble.

For the half century projection (2046 2064), most of the basin will experience decreases in precipitation except the northeast part of the basin that will experience increases under all emissions scenarios. A2 scenario predicted the greatest reduction (26\%) followed by A1B (21\%) and then B1 (17\%). Two percent of the basin located in the northeast will see increases up to $25 \%$ under $\mathrm{A} 2$ and $\mathrm{A} 1 \mathrm{~B}$, whereas under B1, 32\% of the basin will experience increases up to $40 \%$. For the one-century future, the reduction will increase to $40 \%, 32 \%$ and $17 \%$ under A2, A1B and $\mathrm{B} 1$ emission scenarios, respectively, only $2 \%$ of the basin will experience increases up to $25 \%$ under all emission scenarios. The most affected area by the reduction located in the south west of the basin which will experience decreases up to $80 \%$ under A2 scenario and up to $60 \%$ under either A1B and B1 scenario.

\subsection{The Impacts of Climate Change on Blue and Green Water}

Fig. 9 captures the anomaly maps of blue water distribution for $\mathrm{A} 2, \mathrm{~A} 1 \mathrm{~B}$ and $\mathrm{B} 1$ scenarios for the periods 2046 2064 and 2080 2100 for the average change of multi-GCM ensemble. For the half-centennial projection (2046 2064), the basin will experience an average reduction of up to $52 \%$ under A2 followed by $47 \%$ under A1B and then $42 \%$ under B1 scenario, however the north of basin will see an average increases up to $17 \%$ under $\mathrm{A} 1 \mathrm{~B}$ and $\mathrm{B} 1$ scenarios and $27 \%$ under A2 scenario. For the one-century future, in the downstream of the basin, the reductions will increase to up to $56 \%, 50 \%$ and $39 \%$ under $\mathrm{A} 2, \mathrm{~A} 1 \mathrm{~B}$ and $\mathrm{B} 1$, respectively. Two percent of the north of the basin will experience increase up $14 \%$ under A2 and A1B scenarios, however under B1 scenario, the increases will be up to $27 \%$. Green water storage will have similar trends to blue water as captured in Fig. 10.

\subsection{Impact of Climate Change on Deep Aquifer Recharge}

Fig. 11 captures the spatial and temporal distribution of deep aquifer recharge. All emissions scenarios projected decrease in both near and far future 


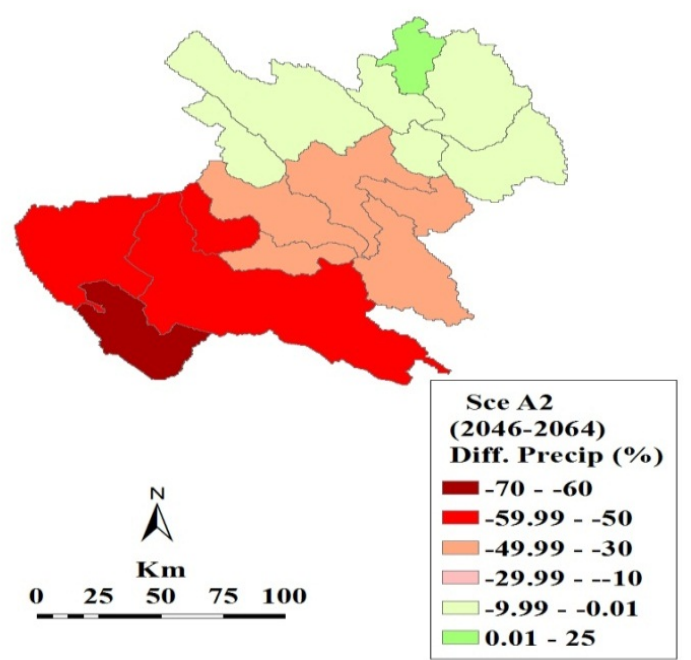

(a)

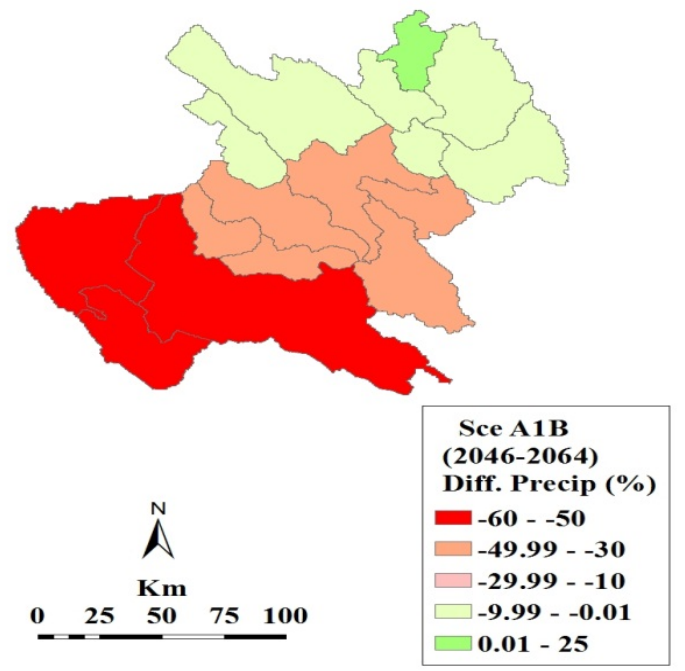

(c)

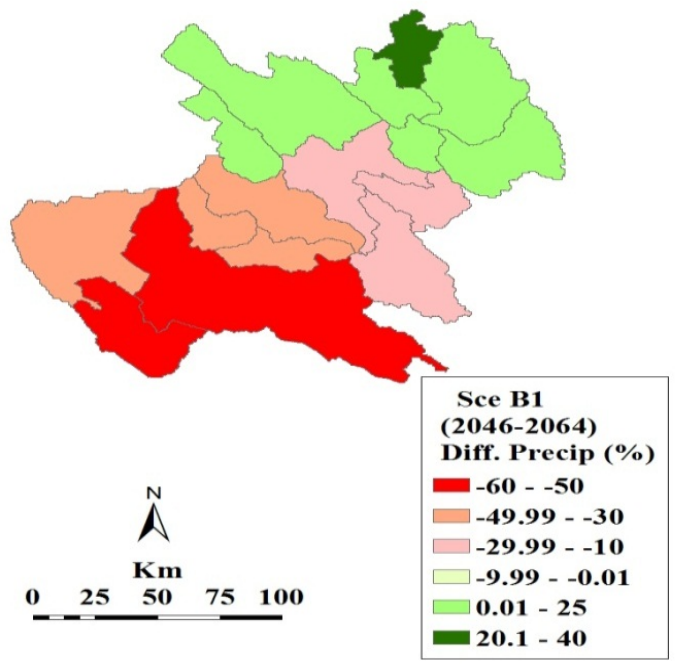

(e)

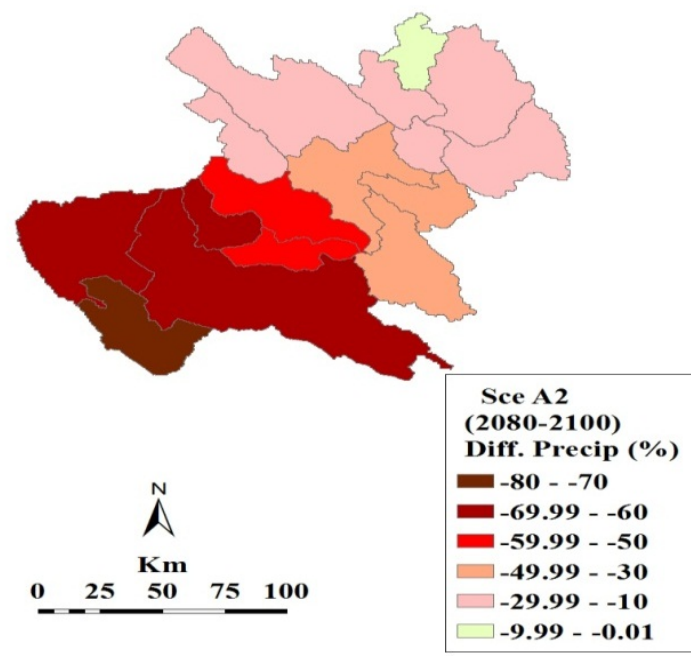

(b)

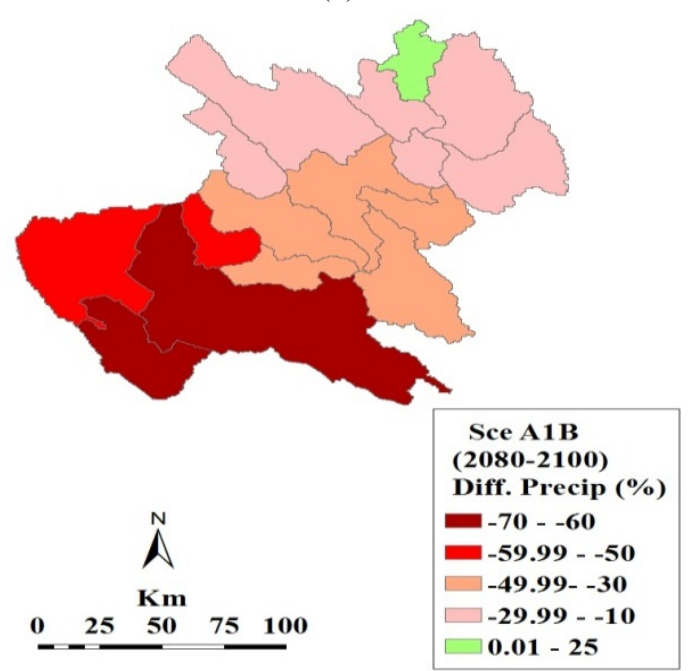

(d)

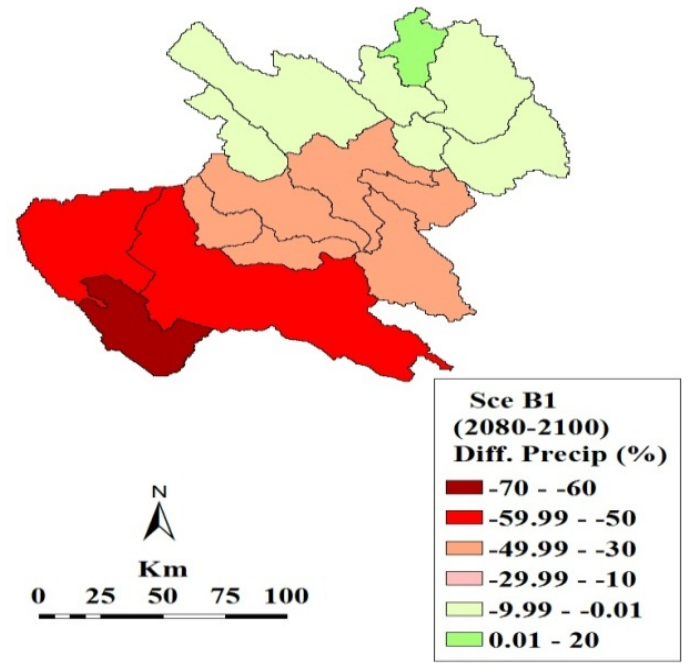

(f)

Fig. 8 The impacts of climate change on the precipitation of the basin: (a) anomaly based on Scenario A2 for the period of 2046 2064; (b) anomaly for A2 to 2080 2100; (c) anomaly for A1B to 2046 2064; (d) anomaly for A1B to 2080 2100; (e) anomaly for B1 to 2046 2064; (f) anomaly for B1 to 2080 2100. 


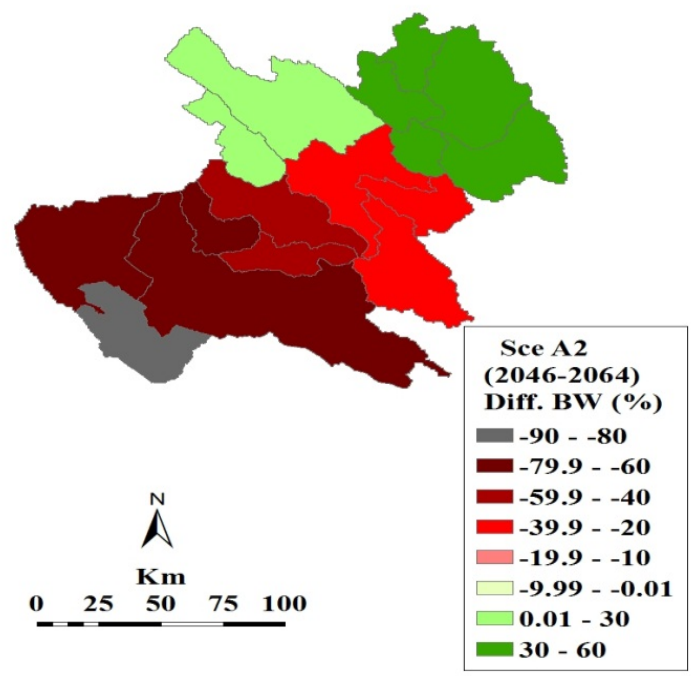

(a)

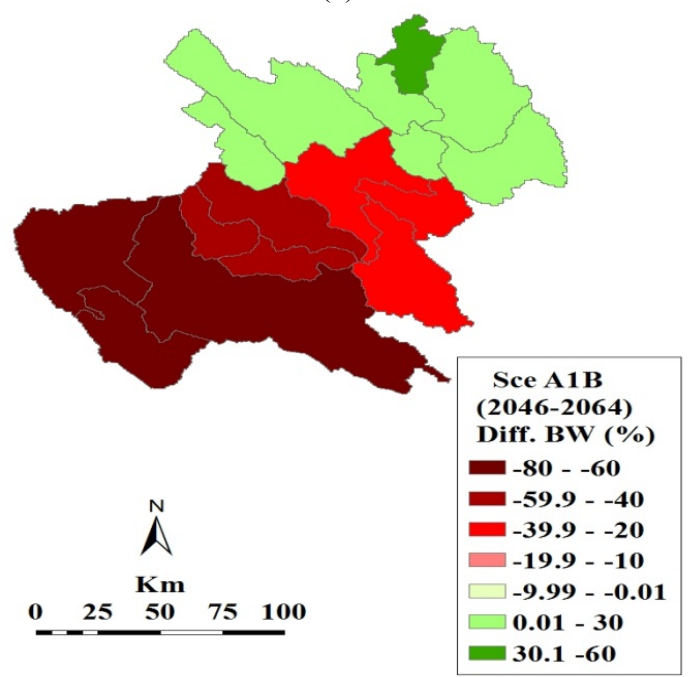

(c)

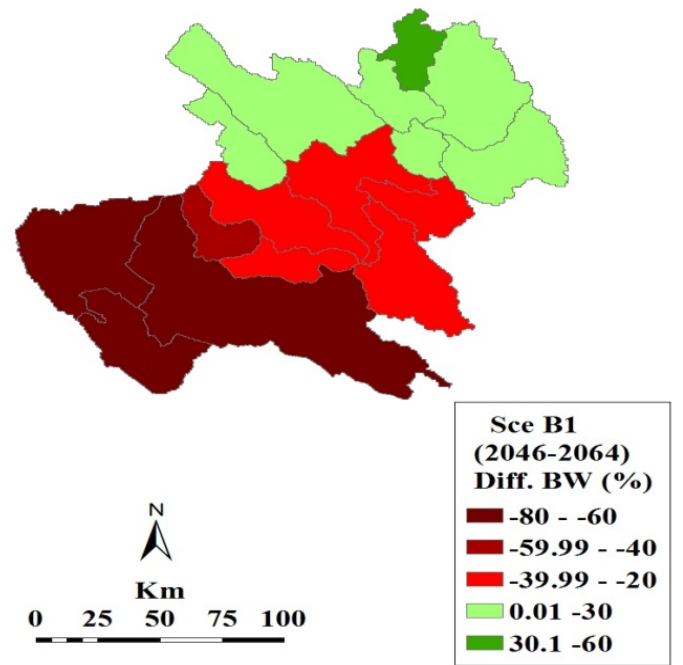

(e)

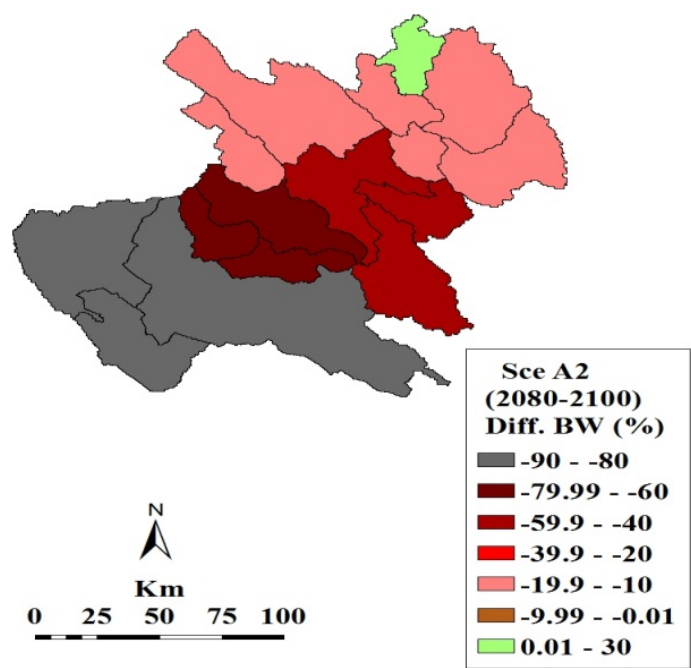

(b)

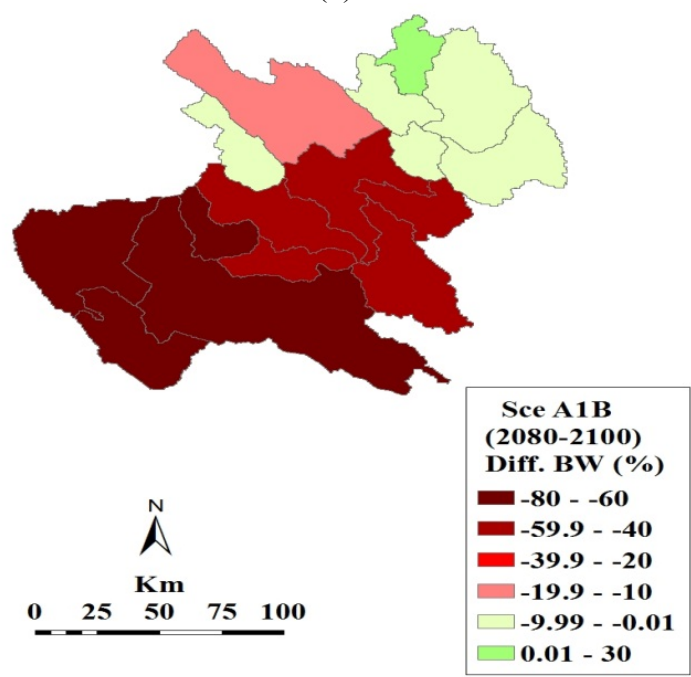

(d)

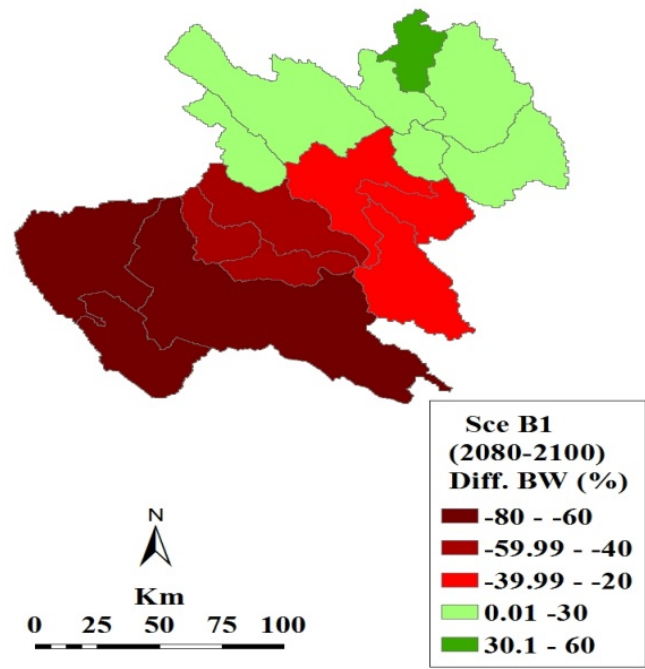

(f)

Fig. 9 The impacts of climate change on the blue water of the basin: (a) anomaly based on Scenario A2 for the period of 2046 2064; (b) anomaly for A2 to 2080 2100; (c) anomaly for A1B to 2046 2064; (d) anomaly for A1B to 2080 2100; (e) anomaly for B1 to 2046 2064; (f) anomaly for B1 to 2080 2100. 


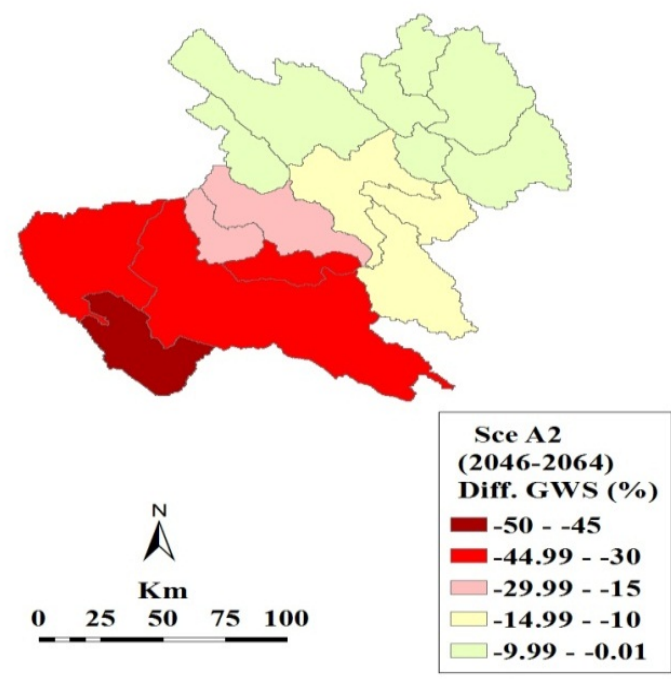

(a)

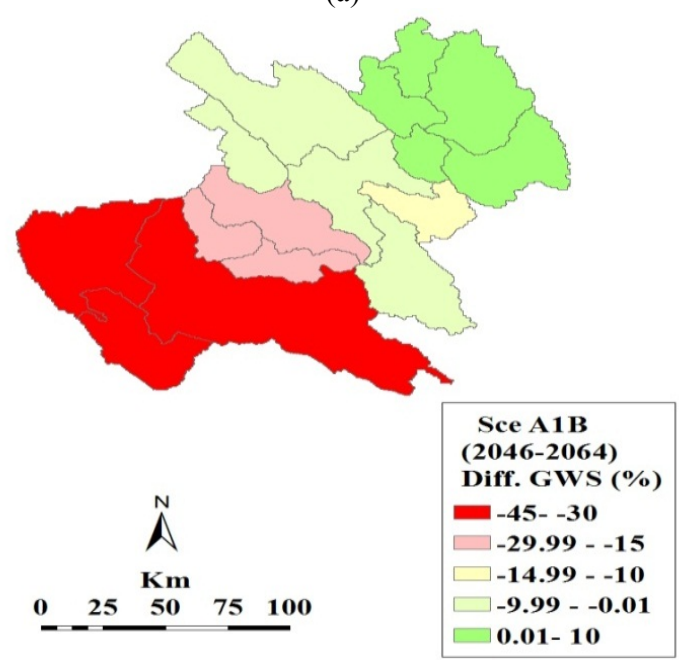

(c)

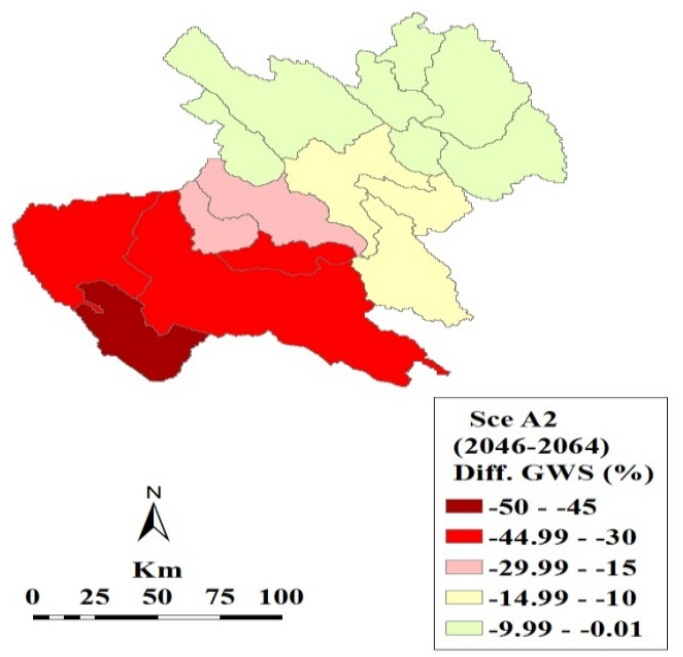

(e)

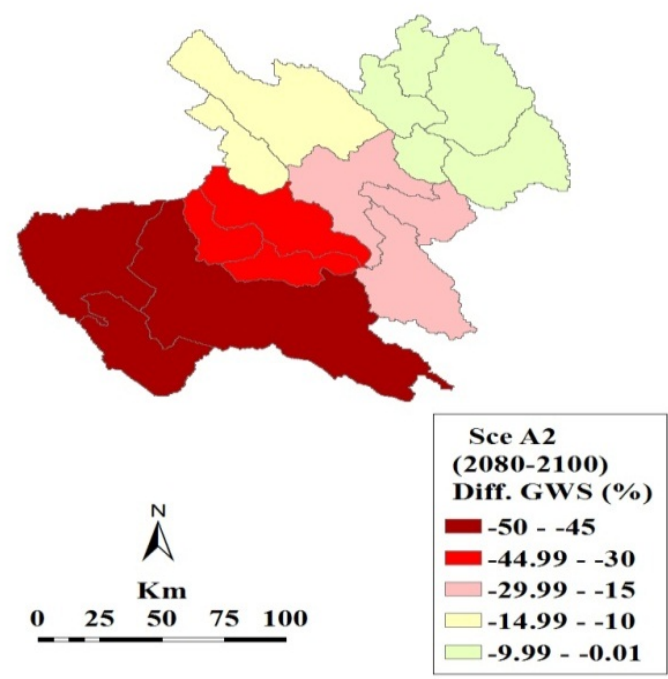

(b)

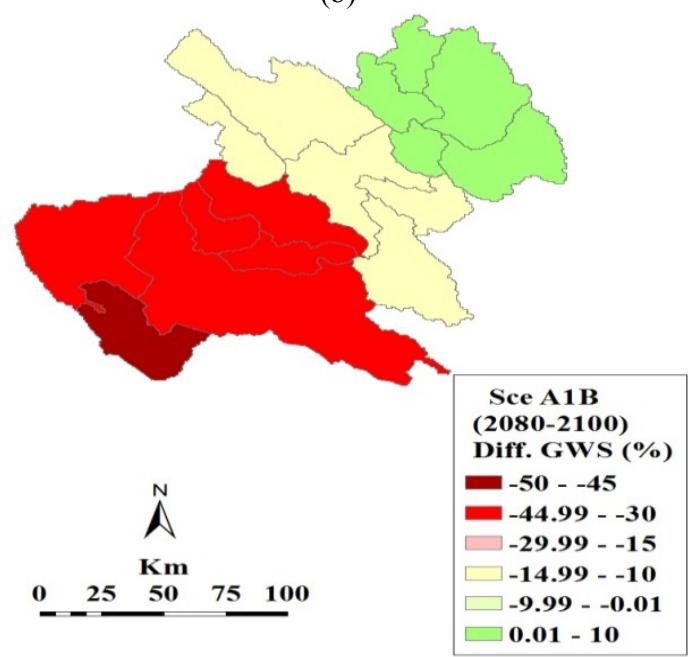

(d)

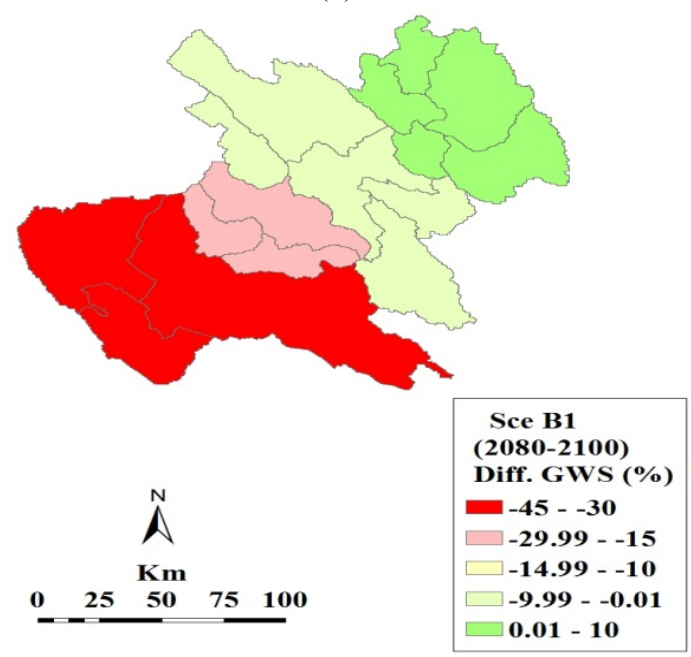

(f)

Fig. 10 The impacts of climate change on the green water storage of the basin: (a) anomaly based on Scenario A2 for the period of 2046 2064; (b) anomaly for A2 to 2080 2100; (c) anomaly for A1B to 2046 2064; (d) anomaly for A1B to 2080 2100; (e) anomaly for B1 to 2046 2064; (f) anomaly for B1 to 2080 2100. 


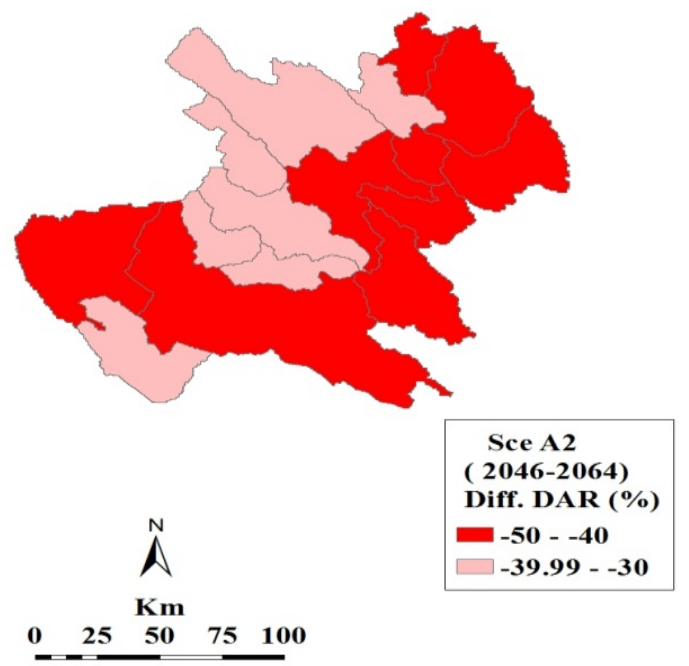

(a)

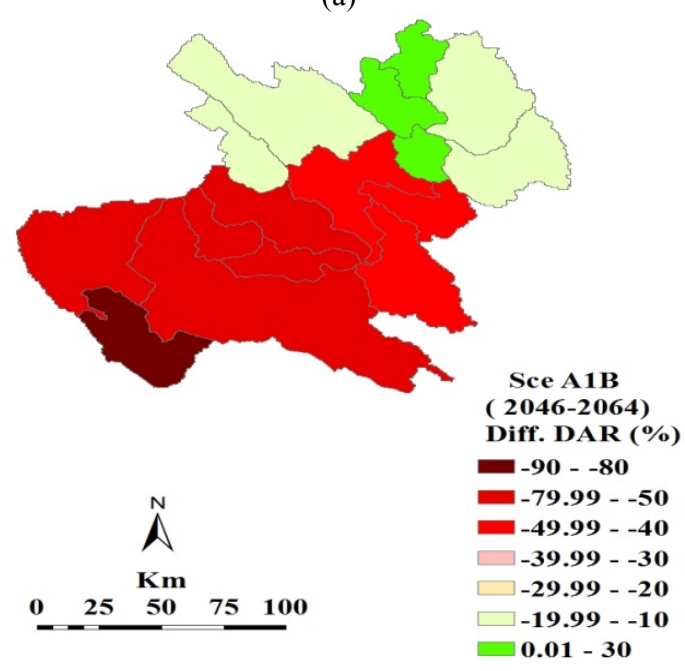

(c)

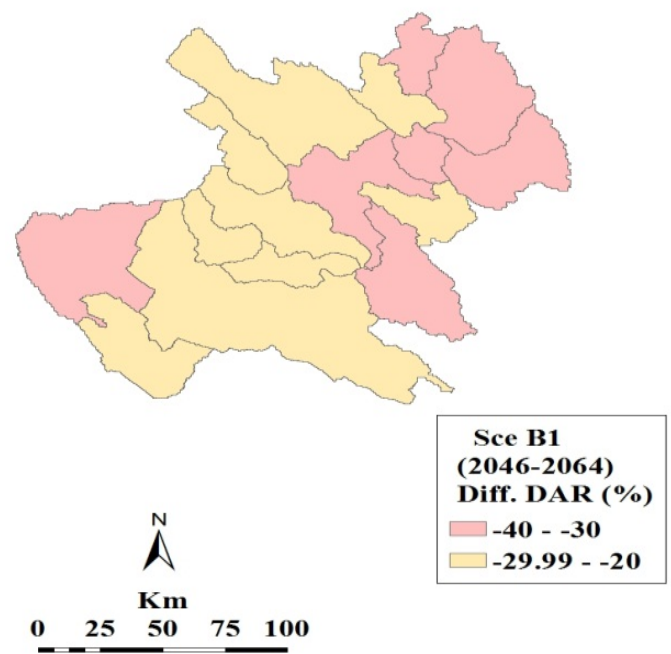

(e)

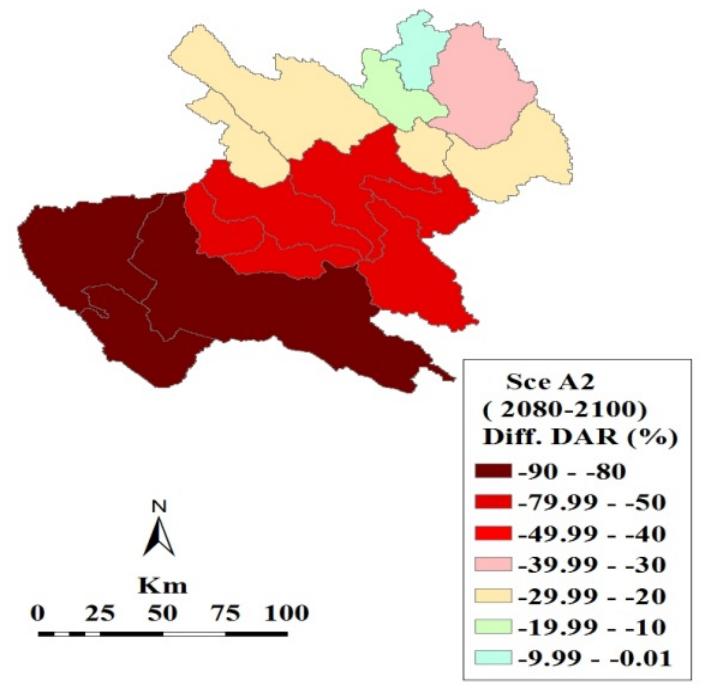

(b)

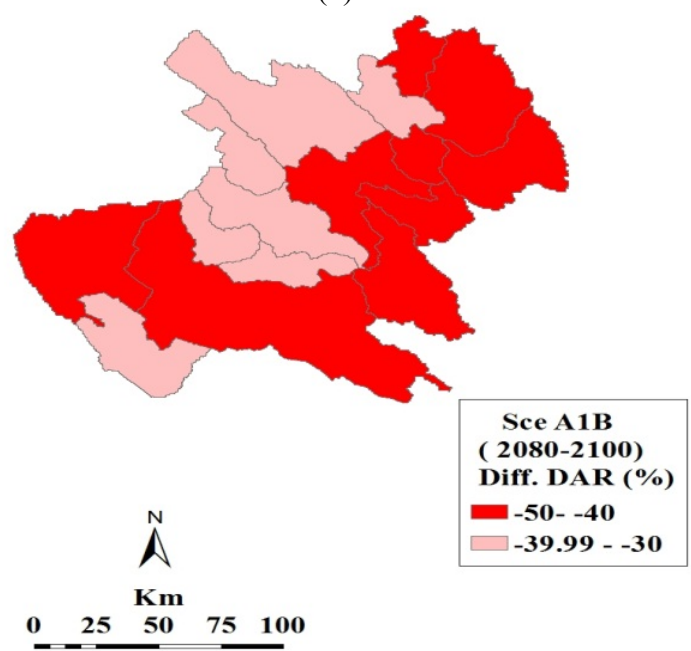

(d)

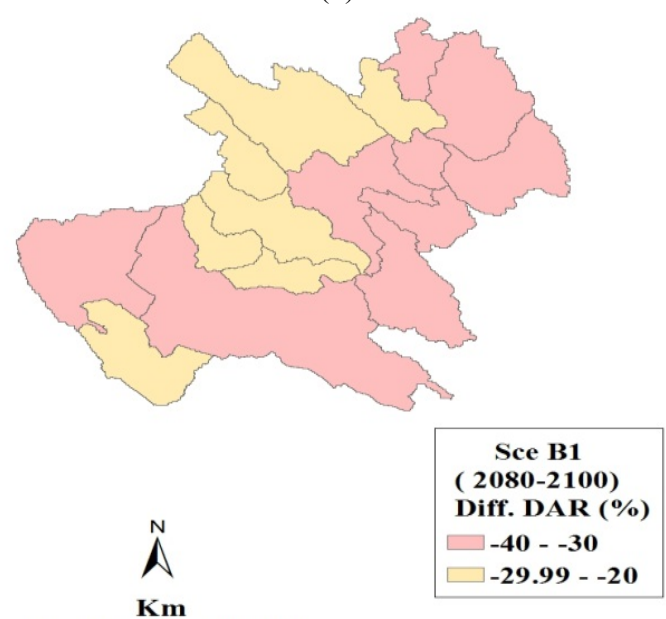

$0 \quad 25 \quad 50 \quad 75 \quad 100$

(f)

Fig. 11 The impacts of climate change on the deep aquifer recharge of the basin: (a) anomaly based on Scenario A2 for the period of 2046 2064; (b) anomaly for A2 to 2080 2100; (c) anomaly for A1B to 2046 2064; (d) anomaly for A1B to 2080 2100; (e) anomaly for B1 to 2046 2064; (f) anomaly for B1 to 2080 2100. 
except small area located in the north basin which will experience increases could reach up to $30 \%$ under A1B scenario for the period of 2046 2064 . 2046 2064 simulations showed decreased by 41\%, $35 \%$ and $28 \%$ under $\mathrm{A} 2, \mathrm{~A} 1 \mathrm{~B}$ and $\mathrm{B} 1$ scenarios, respectively. For 2080 2100 period, the decreases in deep aquifer recharge will increase by $50 \%, 41 \%$ and $30 \%$ under A2, A1B and B1 scenarios, respectively.

\section{Conclusions}

The semi distributed SWAT model was successfully applied for the Diyala basin at monthly time steps. The model was calibrated and validated at Derbendi-Khan hydrological station. The calibration and validation results showed good performance of the model in simulating hydrological processes. The calibrated model was used to identify the impacts of climate change on blue and green waters over last three decades. It was also used to project blue and green waters and deep aquifer recharge for near future (2046 2064) and far future (2080 2100) under three emission scenarios (A2, A1B, B1) using six GCMs. All models under three emission scenarios predicted that most of the catchment will be drier in near and far future except a rather small part located in the north of the basin which will be wetter. The results of this study could contribute to a suitable water resources management and crop production for future.

\section{References}

[1] Mimikou, M. A., Baltas, E., Varanou, E., and Pantazis, K. 2000. "Regional Impacts of Climate Change on Water Resources Quantity and Quality Indicators.” Journal of $\begin{array}{llll}\text { Hydrology } & 234 & \text { (1): } & 95-109 .\end{array}$ doi:10.1016/S0022-1694(00)00244-4.

[2] Winter, J. M., and Eltahir, E. A. B. 2012. "Modeling the Hydroclimatology of the Midwestern United States. Part 1: Current Climate." Journal of Climate Dynamics 38 (3-4): 573-93. doi:10.1007/s00382-011-1182-2.

[3] Xuan, Z., and Chang, N.-B. 2014. "Modeling the Climate-Induced Changes of Lake Ecosystem Structure under the Cascade Impacts of Hurricanes and Droughts." Journal of Ecological Modelling 288: 79-93. doi:10.1016/j.ecolmodel.2014.05.014.
[4] Owor, M., Taylor, R. G., Tindimugaya, C., and Mwesigwa, D. 2009. "Rainfall Intensity and Groundwater Recharge: Empirical Evidence from the Upper Nile Basin." Environmental Research Letters 4 (3): p. 035009. doi:10.1088/1748-9326/4/3/035009.

[5] IPCC (Intergovernmental Panel on Climate Change). 2007. Climate Change 2007: Impacts, Adaptation and Vulnerability: Contribution of Working Group II to the Fourth Assessment Report of the IPCC. Cambridge: Cambridge University Press.

[6] Al-Ansari, N. A. 2016. "Hydro Politics of the Tigris and Euphrates Basins." Engineering 8 (3): 140-72.

[7] Al-Ansari, N. A. 2013. "Management of Water Resources in Iraq: Perspectives and Prognoses." J. Engineering 5 (8): 667-84.

[8] Al-Ansari, N. A., and Knutsson, S. 2011. "Toward Prudent Management of Water Resources in Iraq." $J$. Advanced Science and Engineering Research 1: 53-67.

[9] Al-Ansari, N. A., Ali, A., and Knutsson, S. 2014. "Present Conditions and Future Challenges of Water Resources Problems in Iraq.” J. Water Resources and Protection 6 (12): 1066-98.

[10] Al-Ansari, N. A., Ali, A. A., and Knutsson, S. 2015. "Iraq Water Resources Planning: Perspectives and Prognoses." In Proceedings of ICCCE 2015: XIII International Conference on Civil and Construction Engineering, 2097-108.

[11] UN-ESCWA (United Nations Economic and Social Commission for Western Asia) and BGR (Bundesanstalt fürGeowissenschaften und Rohstoffe). 2013. Inventory of Shared Water Resources in Western Asia. Beirut.

[12] Issa, I. E., Al-Ansari, N. A., Sherwany, G., and Knutsson, S. 2014. "Expected Future of Water Resources within Tigris-Euphrates Rivers Basin, Iraq." J. Water Resource and Protection 6 (5): 421-32.

[13] Hamza, N. H. 2012. "Evaluation of Water Quality of Diyala River for Irrigation Purposes." Evaluation 5 (2): 82-98.

[14] Al-Faraj, F. A., and Scholz, M. 2014. "Incorporation of the Flow Duration Curve Method within Digital Filtering Algorithms to Estimate the Base Flow Contribution to Total Runoff." Water Resources Management 28 (15): 5477-89.

[15] Arnold, J. G., Srinivasan, R., Muttiah, R. S., and Williams, J. R. 1998. "Large Area Hydrologic Modeling and Assessment Part I: Model Development 1.” Journal of American Water Resources Association 34 (1): 73-89.

[16] Nietsch, S., Arnold, J., Kiniry, J., Williams, J., and King, K. 2005. Soil and Water Assessment Tool Theoretical Documentation. Version 2000. Texas Water Resource Institute, College Station, TX.

[17] Green, W. H., and Ampt, G. 1911. "Studies on Soil 
Physics, 1. The Flow of Air and Water through Soils." $J$. Agric. Sci 4 (1): 1-24.

[18] Monteith, J. 1965. "Evaporation and the Environment in the State and Movement of Water in Living Organisms." In Proceedings of Society for Experimental Biology, Symposium No. 19, 205-34.

[19] Priestley, C. H. B., and Taylor, R. J. 1972. "On the Assessment of Surface Heat Flux and Evaporation Using Large-Scale Parameters." Mon. Weather Rev. 100: 81-2.

[20] Hargreaves, G. L., Hargreaves, G. H., and Riley, J. 1985. "Agricultural Benefits for Senegal River basin." Journal of Irrigation and Drainage Engineering 111 (2): 113-24.

[21] FAO (Food and Agriculture Organization). 1995. The Digital Soil Map of the World and Derived Soil Properties. Version 3.5. Rome: FAO.

[22] Abbaspour, K. C., Yang, J., Maximov, I., Siber, R., Bogner, K., Mieleitner, J., Zobrist, J., and Srinivasan, R. 2007. "Modelling Hydrology and Water Quality in the Pre-alpine/Alpine Thur Watershed Using SWAT." Journal of Hydrology 333 (2): 413-30.

[23] Abbaspour, K., Johnson, C., and Van Genuchten, M. T. 2004. "Estimating Uncertain Flow and Transport Parameters Using a Sequential Uncertainty Fitting Procedure." Journal of Vadose Zone 3 (4): 1340-52.

[24] Yang, J., Reichert, P., Abbaspour, K., Xia, J., and Yang, H. 2008. "Comparing Uncertainty Analysis Techniques for a SWAT Application to the Chaohe Basin in China." Journal of Hydrology 358 (1): 1-23.

[25] Schuol, J., Abbaspour, K. C., Yang, H., Srinivasan, R., and Zehnder, A. J. 2008. "Modeling Blue and Green Water Availability in Africa." Journal of Water Resources Research 44 (7): W07406.

[26] Nash, J., and Sutcliffe, J. V. 1970. "River Flow Forecasting through Conceptual Models Part I-A Discussion of Principles." Journal of Hydrology 10 (3): 282-90.

[27] Legates, D. R., and McCabe, G. C. 1999. "Evaluating the Use of 'Goodness-of-Fit' Measures in Hydrologic and Hydroclimatic Model Validation." Journal of Water Resources Research 35 (1): 233-41.

[28] Moriasi, D., Arnold, J., Van Liew, M., Bingner, R.,
Harmel, R., and Veith, T. 2007. "Model Evaluation Guidelines for Systematic Quantification of Accuracy in Watershed Simulations." Soil \& Water Division of American Society of Agricultural and Biological Engineers 50: 885-900.

[29] Hegerl, G. C., Von Storch, H., Hasselmann, K., Santer, B. D., Cubasch, U., and Jones, P. D. 1996. "Detecting Greenhouse-Gas-Induced Climate Change with an Optimal Fingerprint Method.” Journal of Climate 9 (10): 2281-306.

[30] ASCE (American Society of Civil Engineers). 1993. "Criteria for Evaluation of Watershed Models." Journal of Irrigation and Drainage Engineering 119 (3): 429-42.

[31] Raghavan, S. V., Tue, V. M., and Shie-Yui, L. 2014. "Impact of Climate Change on Future Stream Flow in the Dakbla River Basin.” Journal of Hydroinformatics 16 (1): 231-44.

[32] Maurer, E. P., Brekke, L., Pruitt, T., Thrasher, B., Long, J., Duffy, P., Dettinger, M., Cayan, D., and Arnold, J. 2014. "An Enhanced Archive Facilitating Climate Impacts and Adaptation Analysis." Bulletin of the American Meteorological Society 95 (7): 1011-9.

[33] Setegn, S. G., Srinivasan, R., and Dargahi, B. 2008. "Hydrological Modelling in the Lake Tana Basin, Ethiopia Using SWAT Model." The Open Hydrology Journal 2 (1): 49-62.

[34] Cibin, R., Sudheer, K. P., and Chaubey, I. 2010. "Sensitivity and Identifiability of Stream Flow Generation Parameters of the SWAT Model." Hydrological Processes 24 (9): 1133-48.

[35] Falkenmark, M. 1989. "The Massive Water Scarcity Now Threatening Africa: Why Isn't It Being Addressed?." Ambio. 18 (2): 112-8.

[36] Rijsberman, F. R. 2006. "Water Scarcity: Fact or Fiction?." Journal of Agricultural Water Management 80 (1): 5-22.

[37] Zang, C., Liu, J., Velde, M., and Kraxner, F. 2012. "Assessment of Spatial and Temporal Patterns of Green and Blue Water Flows under Natural Conditions in Inland River Basins in Northwest China." Hydrology and Earth System Sciences 16 (8): 2859-70. 